\title{
1. Institutions as reference points for parents-to-be in European societies: a theoretical and analytical framework
}

\author{
Daniela Grunow and Gerlieke Veltkamp
}

\section{INTRODUCTION}

Raising children is a fundamentally important human act. Parenting understood as allocating time and resources to one's children - is essential to secure the survival and well-being of children and societies at large. European societies promote distinct gender ideologies of how new parents should allocate their time and resources, thereby directing fathers and mothers to have particular experiences in these emotionally significant relationships (Kremer 2007). These gender ideologies, so we claim, are intertwined with the roles ascribed to the state, market and family in the provision of paid and unpaid forms of work and care. While ascribing unpaid housework and care exclusively to women has been an outcome of the industrial revolution (Pinchbeck 2013; Tilly 1994; Tilly and Scott 1987), new ascriptions have been debated and negotiated on several societal levels since. In the context of parenthood, key actors where these negotiations can be observed are dual-earner couples expecting their first child. At present, the majority of new mothers, but few new fathers, adjust their employment in favour of childcare, thereby accepting negative career consequences, including financial dependence on their partner or the welfare state. These gendered choices penalize women and contribute to persistent gender inequalities in European societies. If we are to undergo a fundamental change in how paid work and care work are divided between men and women in the twenty-first century, we argue that dual-earner parents will be the pioneers. The degree to which these couples are in a position to rethink and negotiate motherhood and fatherhood is, we suggest, highly dependent on the policy context in which couples find themselves. It is therefore necessary to observe 
dual-earner couples in different European societies, which represent different sets of gender ideologies and institutional frameworks for working parents.

From the perspective of the couples themselves, the transition to parenthood is a unique experience. In particular, the transition to parenthood is 'ethical' in two primary ways. First, it is intertwined with how parents-to-be 'see themselves as parents, how they wish to relate to their children and what kind of human beings they want their children to be' (Ramaekers and Suissa 2010, p. 182). Second, raising a child is associated with 'being part of a community, upholding a good society and introducing children into the world' (Ramaekers and Suissa 2010, p. 185).

\section{Levels of Analysis Provided in this Book}

First, this book investigates men and women in expectant dual-earner couples and the ways they plan and envision their life as mothers and fathers after the birth of their first child. The 'couple' perspective used in this book emphasizes the fact that individual plans and experiences relating to gender ideologies are inevitably linked to the plans and experiences of others, most often the partner (Elder 1998). We describe how couples attempt to synchronize their work and care plans during the transition to parenthood and which individual strategies men and women use to adapt as a couple. We follow these couples from pregnancy to the early stages of parenthood in a series of two edited volumes. In this first volume we meet the couples as parents-to-be, who share their plans and expectations about the future with us. We learn of their plans for the provision of care for their yet-unborn baby and their future as (working) parents. We also learn where the couples seek and find orientation in negotiating their plans and forming expectations, at a time when they anticipate something they have not yet experienced. Interviewing couples during this early stage of parenthood enables us to examine the social context that surrounds them and how this context influences their plans.

Second, this book will examine the social context in eight selected European societies in which the couples shared their journey to parenthood with us: Sweden, Germany, the Netherlands, Switzerland, Italy, Spain, the Czech Republic and Poland. The order in which the countries are presented in this volume follows their specific institutional commonalities and differences, which will be discussed in the remainder of this chapter as well as in Chapter 2. The selected countries are theoretically interesting because they reflect the substantial variation in how public and private responsibilities towards care can be viewed and valued. 
Variation also exists with respect to path dependencies in welfare state development and family policy reform. Macro-level gender ideologies prevailing in different country contexts - and their institutional representations - structure and frame individual experiences of the transition to parenthood in gendered ways, thereby reproducing or justifying existing gendered power differences. In this first volume we establish a comparative framework across the selected countries, which allows us to link individuals' and couples' plans and expectations to the wider national context surrounding them.

Third, this book provides detailed information on eight national contexts and the ways in which they promote - or fail to promote gender equality. Throughout the late twentieth and early twenty-first century the northern European countries, most notably Sweden, have been at the forefront of encouraging parents to work and care jointly while their children are young. Hence, the Swedish couples represented in this volume have themselves grown up in a social climate favouring a comparatively high level of gender equity. When making plans for their future as a family and for the gendered division of earning and caring they can also take for granted a high level of institutional support for employed parents.

Institutional support for employed parents has been relatively high in Germany as well, but until very recently focused on enabling extended phases of full-time maternal home care, rather than joint earning and caring by mothers and fathers. The German couples represented in this volume grew up in the former Federal Republic of Germany (FRG), today's western part of Germany, many of them with a stay-at-home mother and a full-time employed father. For these couples, the norm of the 'good' mother who cares for her child full-time during its first years has been and still is a central point of reference. Parents-to-be in the Netherlands grew up with a stay-at-home mother and a full-time employed father as well, but quite abruptly in the 1980s, Dutch policymakers started advocating a new ideal of both parents sharing childcare and paid work after the transition to parenthood (Kremer 2007). Hence, the Dutch couples represented in this volume grew up in a social climate of rapidly changing gender ideology - from traditional to more egalitarian. They find themselves in a context which prompts them to re-define how to be 'good' part-time working parents and care givers to their newborn.

At the other end of the spectrum, which includes Switzerland, Italy and Spain, policymakers have been reluctant to provide legal and financial aid to help families manage care and paid work. In Switzerland, despite lacking national work-family policies, female employment has been 
widespread with female labour force participation rates above 50 per cent already in 1965 (Brewster and Rindfuss 2000, p. 276). The Swiss couples represented in this volume anticipate parenthood in a context in which parents struggle against structural constraints to maternal employment with preferences appearing to have little impact on the gendered workcare arrangements that are ultimately chosen (Stähli et al. 2009).

Women in Spain and Italy started participating in paid work and challenging uneven gendered divisions of unpaid work more recently than their peers in northern Europe. The parents-to-be from Italy and Spain represented in this volume grew up in a social context assuming a male breadwinner and female homemaker, while they themselves both anticipate, in order to make ends meet, being full-time (or close-to-fulltime) working parents. They face different kinds of challenges in planning their future and embracing or questioning traditional gender ideologies compared to the couples in northern Europe, not least due to the financial crisis which peaked in 2007 and hit southern Europe particularly hard.

In contrast to their western European peers, the Polish and Czech couples interviewed for this edited volume have grown up under communism, or in the period shortly thereafter - a policy and family context radically different from the national institutional frameworks present today. Most Polish couples have, themselves, been raised by working mothers who carried the dual burden of full-time earning and caring (stylized in the ideal of the 'matka polka', the 'polish mother') while the role of fathers was weak under communism. The Polish parents-to-be represented in this volume are a highly selective and privileged group, sharing egalitarian gender ideologies and a cosmopolitan life style. However, ideals of gender equity in parenting lack institutional support in Poland. The Czech couples represented in this volume experienced low quality, state-provided childcare as children under communism, leading to them rejecting institutionalized childcare for their future child. Czech mothers are now entitled to long institutionally supported care leaves, signalling that maternal employment is secondary to providing care. In this respect, the Czech context reflects a turn towards traditional gender ideology and gendered separate spheres.

\section{The Concept of Gender Ideologies Applied in this Book}

Our focus in this book is on gender ideologies in the specific domain of family formation and hence on ideologies concerning men's roles as working and caring fathers and women's roles as working and caring mothers. We assess gender ideologies on two analytical levels. First, at 
the macro-level we refer to gender ideologies as widespread societal beliefs that legitimate gendered power differences and inequality by making them seem 'natural' (Lorber 1994, p. 30). Such beliefs are reflected in dominant family models (Pfau-Effinger 2005), as well as in legal institutional structures, that is, family policies. We refer to this macro-analytical level of gender ideologies as gender culture. Gender culture thus represents 'fundamentally cultural values that together construct the idea of the "ideal" family form' (Pfau-Effinger 2012, p. 533). Second, we consider micro-level individual gender ideologies, expressed as 'individuals' levels of support for a division of paid work and family responsibilities that is based on the belief in gendered separate spheres' (Davis and Greenstein 2009, p. 87). We consider gender ideologies as distinct from, though closely related to, gender identities, which relate to social-psychological constructions of the gendered self, and attempt to assess how individuals' beliefs relate to their own lived experiences (Hochschild and Machung 2012 [1989]). We refer to strong beliefs in gendered separate spheres as traditional gender ideologies and to beliefs embracing equal and shared contributions to these spheres by men and women as egalitarian gender ideologies (Ritzer 2007). More recently, research points to an increase in gender ideologies which mix various aspects of egalitarian and traditional gender ideals, such as intensive parenting (Wall 2010) and egalitarian essentialism (Charles and Grusky 2004). Consequently, we conceptualize and assess gender ideologies as a multi-dimensional concept according to which beliefs in joint family responsibilities may not coincide with beliefs in joint earning, and experiences, including the formation of motherhood and fatherhood identities, which may deviate from individual and shared beliefs.

\section{Research Question and Motivation}

All over Europe, the social conditions under which couples become parents today differ markedly from those of their parents' generation. Unlike earlier cohorts, young women and men today tend to have quite similar life experiences and skills when they form a couple and decide to start a family (Blossfeld 2009). Processes such as educational attainment, first intimate relationships, cohabitation, labour market entry and early employment careers vary across social classes and between countries, but decreasingly vary by gender (Blossfeld et al. 2005; Nazio 2007). In line with these changes, a significant increase in educational homogamy, or non-traditional resource matches, understood as similar levels of educational attainment or earnings among male and female partners, has been found in European countries (Blossfeld and Timm 2003). This trend 
is mirrored by more egalitarian gender ideologies held by younger cohorts (Davis and Greenstein 2009; Dorius and Alwin 2010; Lück 2006; Pfau-Effinger and Euler 2014). Since both sexes are more highly educated compared to their parents' generation, have more similar labour market experiences and enter couple relationships on more equal terms, scholars interested in the gendered division of labour expected to observe more gender egalitarian divisions of paid and unpaid work among these couples and families. Instead, research consistently shows that the decrease in traditional family arrangements has been moderate, leading to a widening gap over time between increasingly egalitarian gender ideologies and actual patterns of behaviour (Davis and Greenstein 2009; Grunow, Schulz and Blossfeld 2012). But why would couples sharing egalitarian gender ideologies and living fairly egalitarian lives adopt traditional gender practices? The answer provided by the social sciences to this question is yet incomplete.

This is the intellectual starting point of this edited volume. Available evidence suggests that the historical persistence of traditional divisions of labour among couples - the stalled revolution (England 2006, 2008) - is largely driven by three processes. First, compared to older cohorts or age groups, young couples today actually do divide paid and unpaid work more equally during early stages of the life course (Bühlmann, Elcheroth and Tettamanti 2010; Fuwa and Cohen 2007). Second, in many countries these initial egalitarian divisions are followed by a traditionalization of gender roles over the course of family formation (Evertsson and Nermo 2007; Fox 2009; Grunow, Schulz and Blossfeld 2012; Kühhirt 2012; Miller 2007, 2010; Schober 2013). Third, patterns of labour division established upon entering parenthood have been found to persist during later stages of the life course (Deutsch 1999; Gershuny, Bittman and Brice 2005; Grunow, Schulz and Blossfeld 2012; Hays 1996; Walzer 1998). This suggests that couples adapt formerly egalitarian gender ideologies and practices to less egalitarian realities in the process of family formation (Baxter et al. 2014; Bühlmann, Elcheroth and Tettamanti 2010; Kaufmann 1998). Yet, little is known about how egalitarian and traditional gender ideologies conflict or change over the adult life course and how individuals then create and maintain their gender identities in the early stages of family formation and beyond.

Hence, the transition to parenthood is especially salient when it comes to assessing change and persistence of gendered separate spheres because it appears to trigger a traditionalization among formerly egalitarian couples. Couples' plans to change their division of labour after the transition to parenthood, which we study in-depth in this volume, are thus crucial for gender inequality in the household, and have long-term 
consequences for gender inequalities in the labour market (for example, Charles and Grusky 2004; Mandel and Semyonov 2006; Ruhm 1998). Furthermore, understanding how and why parenthood leads to traditional gendered divisions of labour is vital to understanding other aspects of social change. Traditional divisions of labour have been found to lower the intention to have another child (Mills et al. 2008) and to increase the risk of divorce (Cooke 2004), while higher educated parents' joint contributions to paid and unpaid work have been found to be positively associated with the time both parents spend individually and jointly with their children (Bonke and Esping-Andersen 2011, pp. 51-52). It is therefore surprising that the question of why couples currently adapt their division of paid work and care work the way they do has so far received little attention (Fox 2009). The aim of this book is to provide some tentative answers to this question by (a) providing evidence of how couples in different institutional and cultural contexts plan to adapt following a first birth and (b) analysing the reasons that expectant fathers and mothers give for why they plan to adapt the way they do. By linking these two levels of analysis we aim to systematically explore how macroand micro-level gender ideologies and their fit with existing family policy frameworks influence identity formation and actual patterns of conduct in this crucial phase of men's and women's life courses.

\section{What We Do in This Book and Why}

The chapters assembled in this edited volume provide novel insights into how dual-earner couples in distinctly different national contexts decide how to divide paid and unpaid market and familial work during the transition to parenthood. Expectant parents' accounts of what is 'right', 'natural' or 'in the child's best interest' serve as an analytic lens to assess context-specific gender ideologies during this crucial life-course transition. We conducted and analysed separate interviews with pregnant women and their male partners in eight European countries. ${ }^{1}$ We interviewed these expectant first-time parents about their existing division of labour as well as their future plans regarding gendered divisions of housework, parental tasks, leave taking, employment interruptions, working-time adjustments and use of childcare. Interviewing expectant first-time parents during late pregnancy has a methodological advantage for cross-national research because we compare these couples at a similar and crucial stage of their life course (Grunow 2006). Furthermore, the phase of late pregnancy is theoretically important because couples have to make binding and consequential decisions about their individual careers and family life despite uncertainty about the future. Hence, rather 
than looking at the past experiences of parents, we investigate expectant parents' beliefs and ideas about their future as parents. ${ }^{2}$ We argue that these data are especially suited to identify context-specific dominant gender ideologies. Our study shows where couples seek and find guidance in this crucial phase of anticipating parenthood and how cultural and structural contexts frame the formation of identities of women as mothers and men as fathers.

The samples obtained in the country studies reflect our interest in dual-earner couples with similar educational levels and higher earnings. We refer to these couples as non-traditional resource matches because the male partner has rather similar or even lower earnings and employment prospects compared to the female partner. Non-traditional resource matches are frequent among the couples analysed in this volume, nonetheless, other constellations can also be found (see the Appendix at the end of the book). Many of these couples practised an egalitarian gendered division of paid work at the time of the first interview, and thus challenged the notion of gendered separate spheres in everyday life. Most of them were in a position where they were able to 'plan' the timing of parenthood, and therefore, also able to consider and negotiate its terms. If couples nowadays hold egalitarian gender ideologies and if they indeed desire to alter gender practices in the family, we expect it will be the well-educated, dual-earner 'family planners' that have the intention and resources to do so. The consequence of this methodological and theoretical choice is that we will not be able to assess how couples' social class position influences plans concerning their work and family balance and the formation of gendered parenting identities. We also do not provide evidence that is statistically representative for parents-to-be in a given country (except Evertsson, Chapter 2 in this volume). In particular, our focus on heterosexual dual-earner couples excludes social groups such as single mothers and fathers-to-be as well as same-sex couples expecting their first child. The advantage of this sampling strategy is that the couples observed share important characteristics that make certain aspects of their individual accounts comparable across cases, both within and across countries (see Chapter 3).

\section{THEORETICAL MECHANISMS INVESTIGATED IN THIS BOOK}

All structural theories must make assumptions about individuals, and individualist theories must make presumptions about external social control. While we do gender in every social interaction, it seems naive to ignore the 
gendered selves and cognitive schemas that children develop as they become cultural natives in a patriarchal world.

(Risman 2004, p. 430)

In this section we provide an analytical framework that allows us to link national macro-level institutions to the individual and couple-level processes of (a) decision-making and action, and (b) identity formation among women as mothers and men as fathers. We frame the macro-level institutions of interest for our research question in terms of specific features of the welfare state on the one hand and gender culture on the other. Even though actual practices of mothering and fathering may vary, cultural ideas about mothers and fathers often continue to be constructed as distinct and complementary, with motherhood linked to assuming the main responsibility for the child and fatherhood associated with providing the main family income (Hobson and Fahlén 2009). These complementary constructions are closely connected to beliefs in parents' distinct gender dispositions, for instance beliefs in 'maternal love' and a naturally developing 'maternal instinct', signifying the distinctive quality of maternal care due to the existence of a special bond between the mother and the child. Proponents of this perspective often highlight the biological processes of pregnancy and breastfeeding as unique to motherhood, thus 'naturally' marginalizing fathers' capacity to develop paternal love and instinct of a similar strength and quality. Men thus enter fatherhood from a cultural imperative of paid work with the option to engage in care, while women enter motherhood with an imperative of care with the option to engage in paid work (Neale and Smart 2002). The interplay between cultural constructions of motherhood and fatherhood, on the one hand, and welfare state policies on the other, form distinct gender regimes within which the parents-to-be represented in this volume experience their journey to parenthood.

\section{The Interplay Between Institutions and Agency in the Formation of Parenting Identities}

Gender culture is conceptualized in this volume as a social structure, which is fundamentally embedded in the individual, interactional and institutional layers of societies (Risman 2004). Structural concepts 'must be observable, external to the individual, and independent of individual motivation' (Risman 2004, p. 431). This definition analytically distinguishes between 'institutional structures' as constraints and 'action' as choice under constraints. In line with this perspective Hobson and Fahlén (2009) have shown that fathers' and mothers' options to enact their 
specific ideals concerning work and care differ between national gender regimes. Their analysis builds on Sen's (2003) framework of capability and agency. Agency, a person's fundamental relative autonomy in all circumstances (Hitlin and Elder 2007), is in itself embedded in a specific institutional context and gender regime (see also Emirbayer and Mische 1998; Mahmood 2001). The concept of agency describes an individual person's more or less limited range of possible alternative actions. The perceived alternatives depend largely on the individuals' own past experiences that have been internalized. In contemporary societies, a person's gender structures these experiences from birth onwards; most notably when it comes to family life (Eliot 2012). ${ }^{3}$ Undoubtedly, there will be variation both in these experiences and also in the degree to which they are internalized but for many, these experiences will be gendered. As a consequence, a mother-to-be has typically developed subtle gender dispositions, or a particular feeling of what it means to be a 'good' parent, that differs from a father-to-be (see McNay 1999). These feelings may thus guide gendered action as expectant mothers and fathers act and react in accordance with what feels 'right' to them. They may reflect on some of their feelings and actions but take others for granted.

From a life-course perspective, gender dispositions that concern 'care' usually first become observable in adult gender practices when men and women start forming a family of their own. Gendered dispositions are neither a universal gender process nor a random individual set of dispositions, because they are shaped by men's and women's direct structural and relational contexts in a specific country (McNay 1999). Against this background our aim is to investigate how fathers and mothers-to-be choose one alternative of balancing paid work and care work over another, how these actions cohere with the formation of gendered parenting identities, individual gender ideologies and the ways in which both relate to different gender regimes.

We presume that actors choose the alternatives they consider 'right' or 'best', given imperfect information about the full range of options and the future consequences of their choices (cf. Gigerenzer and Todd 1999; Simon 1972). ${ }^{4}$ Instead of trying to gather complete information about all possible alternatives and their future outcomes, couples expecting their first child find guidance in their institutional context to make a satisfying, 'good enough' or 'right' decision under conditions of uncertainty about the future. The institutional context is neither static nor independent from transnational developments or discourses. In this volume, however, we see a snapshot of national institutions that become a point of reference for the couples studied in the country-specific chapters. Institutional points of reference include the gender culture, mass media displays of 
parental roles and normative messages stemming from family policies and other welfare state arrangements (see Figure 1.1). These points of reference are processed, reproduced and altered by all members of a society, including the couples themselves. Some members of society are perceived by couples as relevant others, for instance friends, peers and family members. The actions or expectations of these relevant others towards the couples are formed in the same institutional context. However, they represent selected, interpreted and differentially expressed facets of this context. Relevant others thus usually provide parents-to-be with additional information by means of their own gender ideologies, actions and expectations. Taken together, these various pieces of contextrelated information guide - or 'bind' - decision-making processes and identity formation at the transition to parenthood. We expect that institutions are stronger points of reference the more consistent these various pieces of information are.

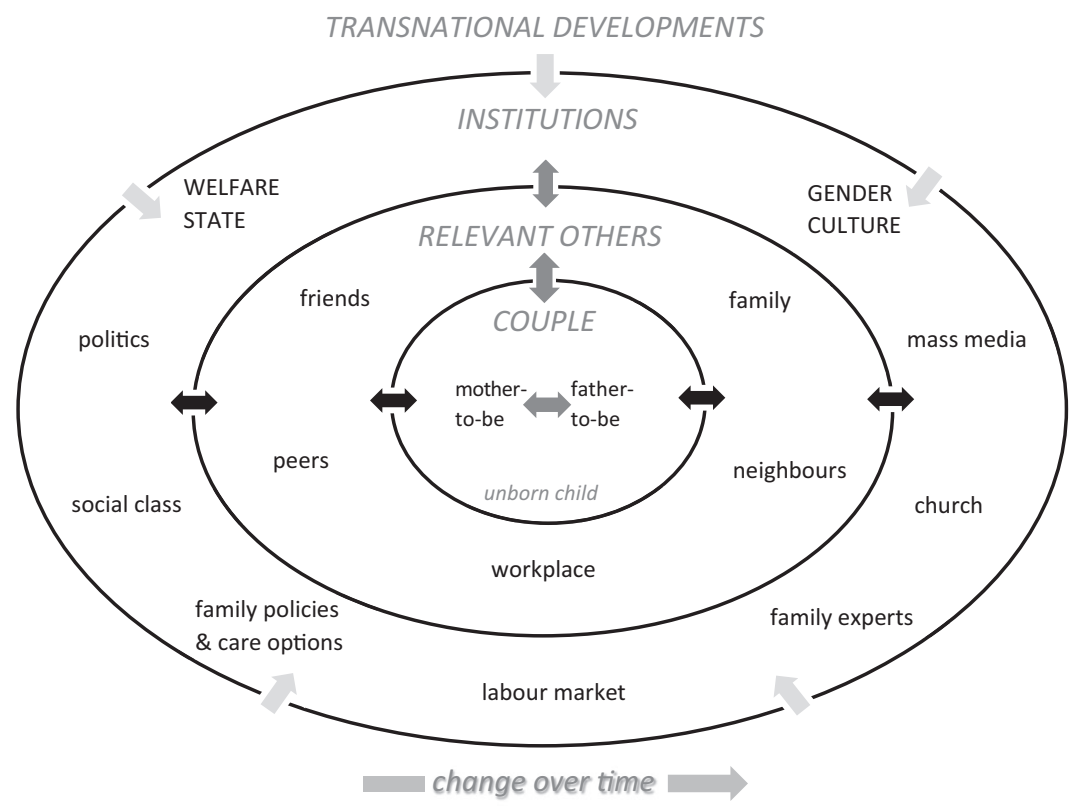

Source: Own depiction inspired by Bornstein and Cheah's (2006, p. 4) 'Contextual ecological view of development'.

Figure 1.1 Institutions as reference points for mothers-and fathers-to-be 
The decisions made during the transition to parenthood may not turn out to serve all new parents' own interests or individual gender ideologies, even if they are a product of individual agency. For instance, working mothers-to-be who would prefer to stay in the labour market may decide to become a homemaker in order to be the main caregiver of their child due to a lack of care alternatives they consider to be 'good enough' (Risman 2004, p. 432). In this example, individual agency is influenced by a perceived lack of reliable options in a given institutional and couple context. Agency is also informed by the entanglement of 'own' preferences, gender ideologies, dispositions and the perceived needs of the yet unborn child. In order to conceptualize the adjustment of individual preferences and orientations in light of what is believed to be realistic during the transition to parenthood we draw on Elster's (1983, p. 25) notion of 'adaptive preference formation'. The driving force behind this 'adaptation' of individual preferences is the aim of reducing tension or frustration caused by wanting things one cannot have under specific circumstances. Conscious decisions that conflict with actual individual preferences or gender ideologies are believed to be backed up over time by processes of adaptive preference formation (Elster 1983). We argue that the alternatives that parents-to-be consider to be reliable, 'right' or 'good enough', and the ways in which they adapt, depend on the normative messages provided in their specific institutional context.

\section{Historical Legacies Reflected in Varying Institutional Contexts}

Informed by historical processes, countries differ in their gender cultures. In a particular country certain groups have been more influential than others in promoting gendered norms. The Catholic Church has, for instance, been influential to different degrees in advancing the ideal of a 'good mother' (Gerber 2010; Gerend 2005), as were middle-class groups and developmental psychologists in broadcasting the importance of a 'resilient' and 'happy' child (Hoffman 2010; Ramaekers and Suissa 2010) and the primacy of mothers (and not fathers) in childcare (Romagnoli and Wall 2012). Governments currently promote different degrees and notions of 'active fatherhood', 'shared parenting' (Kremer 2007) and mothers as primary carers by default. In this sense, various national and regional institutional domains have developed their own internal gendered logics, which are in different ways related to one another (McNay 1999, p. 106) and to other historical and political events.

Likewise, national gender regimes have to varying degrees been informed by supra-national developments, for instance by EU policymaking and the spread of egalitarian gender ideologies. Egalitarian 
gender ideologies have been rising in Europe since the late twentieth century (Beck and Beck-Gernsheim 2002), with the expansion of higher education (van Berkel and De Graaf 1999) and increasing female employment. At the same time, and despite emerging masculinities concerned with 'participating fatherhood' (Bergman and Hobson 2002, p. 93), 'intensive mothering' (Hays 1996; Knaak 2010, p. 349) has become a dominant ideology in western countries over the course of the twentieth century. Intensive mothering refers to a gender culture where the mother is the primary caregiver, who should be self-sacrificing and centre all of her efforts on the child's needs, thereby subordinating her other roles. From the perspective of increased female employment, this can be seen as a contrary movement because the cultural model of intensive mothering emerges '[...] just as the biological components of women's mothering have lessened, as women have born fewer children and bottle-feeding has become available' (Chodorow 1999, p. 5). Gender regimes that strongly embrace intensive mothering thus challenge the identities of gainfully employed and career-oriented mothers. In a "couple' perspective, intensive mothering requires intense involvement of fathers as earners and (secondary) carers in order to enable the childcentred approach to parenting (Wall 2010). Models of 'masculinities' can be understood in a similar sense. A plurality of masculinities can be found in different social and cultural settings, but certain masculinities are more 'socially central or associated with authority and social power' than others (Cornell and Messerschmidt 2005, p. 846). Across countries we therefore expect the couples interviewed in this volume to relate their own views and plans, in both direct and indirect ways, to different dominant gendered constructions prevailing in a specific institutional context.

\section{Doing Gender and 'Special Moneys' Among Dual-Earner Parents}

Gender ideologies frame not only the expectant parents' articulated views and plans, they also shape their behaviour in everyday life (Fenstermaker, West and Zimmerman 1991; Goffman 1976, 1977; West and Zimmerman 1987). Gendered behaviour in everyday life has been labelled 'gender display' as relevant others can observe and evaluate it as appropriate or inappropriate (West and Zimmerman 1987). Gender display includes the domains of housework and paid work as well as notions of care. If traditional gender culture prevails in society, being a caregiver and a homemaker confirms 'femaleness' while being a breadwinner and avoiding care confirms 'maleness' (see also Fenstermaker Berk 1985). Among the dual-earner couples studied in this volume, beliefs in gendered 
separate spheres are not expected to be the norm. First, many of these couples practise a non-traditional division of paid work - and thus non-traditional gender displays in everyday life - when we first meet them during pregnancy. Adopting a traditional division of labour after the birth of their first child will thus be economically disadvantageous for many of them. At the same time, plans to adopt a more traditional division of labour will yield insights concerning what the couples consider appropriate gender displays of motherhood and fatherhood. Second, the couples find themselves in different institutional contexts, with family policies supporting more traditional or more egalitarian practices among parents. These contexts thus impact what is economically rational for the parents-to-be. If dual-earner parents seek to act in line with economic considerations they will weigh their individual earnings against the cost of childcare and the benefits obtained through context specific transfer payments, or lack thereof.

Becker's (1981) Nobel Prize-winning economic theory of the family, as well as various economic bargaining models (see Gupta 2007 for a review), have highlighted the importance of economic positions and resource distribution within couples for the gendered division of labour. These theories predict a more gender-balanced division of paid work and care within dual-earner couples upon entering parenthood. In terms of the household income, which includes both male and female earnings, money greatly determines the degrees of freedom that couples have for negotiating parenthood (Fox 2009). For instance, opting for high quality childcare rather than maternal or paternal care is an option only when couples can financially afford this. Opting for maternal employment or paternal care is further intertwined with specific cultural and institutional influences as money earned by a mother(-to-be) traditionally has a different social meaning than money earned by a father(-to-be) (Zelizer 1989). This finding has been captured by the notion of 'special moneys' (Zelizer 1989). Historically, the father's income was considered to provide for the family's basic needs. A mother's income has, in contrast, been perceived as supplementary and was supposed to be used either for outsourcing childcare, educating the children or for allowing the family some extra pleasures. Even though mothers contribute a high proportion of the household income in many European societies, early twenty-firstcentury (Grunow 2014) research indicates that her earnings - not his are used for outsourcing housework (Gupta et al. 2010). Research further suggests that gender trumps money in couple negotiations about the division of paid and unpaid work (Bittman et al. 2003). Despite this, a high level of cross-national variation remains. Therefore, we expect institutional contexts to impact how the couples studied in this volume 
deal with their 'objective' resources and constraints such as money when deciding about their future division of labour.

What is economically rational for some couples may conflict to varying degrees with the dominant gender culture or individual gender ideologies. In couples where economically rational plans conflict with their own motherhood and fatherhood ideals, we can analytically separate forces of gender culture and of economic circumstances. For instance, a father desiring and planning to become strongly involved as a caregiver while cutting back on his paid work would be swimming against the current of traditional gender culture (Grunow, Schulz and Blossfeld 2012). Depending on the institutional context, this desire will be backed up to varying degrees by welfare state policies and/or the dominant gender culture. Similarly, a mother swims against the current of intensive mothering when she wants to return to her job more quickly than prescribed by the dominant gender culture. Couples may motivate such culturally 'deviant' options either in terms of economic rationality, or by actively 'undoing gender' (Deutsch 2007; Lorber 2000), irrespective of financial constraints or relative income. Research by Ridgeway (2011) suggests, however, that under conditions of uncertainty or disagreement, couples tend to draw on more traditional gender ideologies prevailing in society.

The identity formation model (Bielby and Bielby 1989) assumes that new ways of enacting motherhood and fatherhood lag considerably behind in historical perspective, as individual processes of reconstructing work and parenting identities are embedded in persisting traditional institutional contexts. The countries analysed in this book vary in the degree to which they support traditional gender ideologies. We therefore expect to find cross-national differences in the formation of gendered parenting identities and the plans made by parents-to-be.

\section{GENDER REGIMES AND POLICY-CULTURE GAPS - A CROSS-NATIONAL ANALYTIC SCHEME}

The chapters assembled in this edited volume illustrate how individual parenting identities and taken-for-granted gender ideologies about 'good mothers' and 'new fathers' evolve within the margins of what is institutionally supported. Few studies so far have tried to empirically explore the degree to which gendered parenting beliefs and practices are contextbound (Devereux, Bronfenbrenner and Rodgers 1969; Rubin and Chung 2006). Those scholars who did, have focused mainly on cultural belief systems (Chodorow 1999; Rubin and Chung 2006). Our study seeks to 
complement this research by investigating culture in its interplay with welfare state policies. We claim that cultural explanations alone omit important aspects of how cultural belief systems differ between modern societies and why their influence on gendered choices appears to be weak in some countries but not in others (Bühlmann, Elcheroth and Tettamanti 2010). In support of our claim we first provide evidence illustrating that gender culture is made of several dimensions. Within a certain national context these dimensions may provide contradictory information concerning gender appropriate behaviour. Second, we provide evidence of how gender culture and gender policies currently appear to conflict to varying degrees. We introduce and apply a framework to identify these policy-culture gaps. The smaller these gaps, the more strongly institutions will serve as a point of reference for parents-to-be. The larger these gaps, the more ambiguous institutions will appear and hence, the less helpful for guiding expectant parents' plans and choices.

Recent comparative analyses of welfare states have identified policy dimensions that are especially relevant in the analysis of gender stratification (see Lewis 2006; Pfau-Effinger 2012; Saraceno and Keck 2011). The analytic perspective applied in this book draws on approaches which emphasize the role of care and culture for attaining gender equality in Europe (Kremer 2007; Saraceno and Keck 2011). We draw on three dimensions of welfare state policies that appear most relevant with respect to the comparative analysis of transitions to parenthood. First, the promotion of fathers as carers is a key dimension to compare across countries. In particular we assess whether fathers are granted paid parental leave, paternity leave, or whether states offer extended leave, conditional on parents sharing their leave entitlement (for details see Chapter 2 in this volume). For the couples studied in this volume these conditions enable or limit paternal care for the child and hence shape couples' plans for the future. Second, the degree to which the state promotes mothers' decommodification through defamilialization largely determines their labour supply, most importantly by means of providing high quality childcare for infants and toddlers. Decommodification is defined as the degree of a person's (in)dependence from paid work in order to satisfy basic needs (Esping-Andersen 1990, 1999; Orloff 2003). Independence from paid work may be attained through access to resources provided by other family members or by the state. Policies promoting childcare and maternal employment are labelled 'defamilialization policies'. Policies supporting the provision by other family members are labelled 'supported familialism'. The extent to which the state views mothers of young children as paid workers allows them to remain financially independent of state or breadwinner support. It also 
provides a normative point of reference in terms of how much of an earner a mother can be, as specific childcare regulations and coverage rates determine how childcare is generally used and which forms of childcare are seen as acceptable. Moreover, it influences the standard way of combining work and care obligations in a given society. A different ideological message - unless combined with the promotion of fathers as carers or defamilialization policies - is sent by policies strengthening mothers' decommodification through supported familialism. Supported familialism is thus the third welfare state policy dimension analysed comparatively in this volume. Supported familialism is promoted by welfare states by means of offering mothers phases of paid and job-protected parental leave. On the one hand, paid leave provides employed mothers with time to care for their newborn. It also is an acknowledgement of the care work provided by mothers (Saraceno and Keck 2011). On the other hand, extended phases of leave have been found to weaken mothers' labour force attachment and therefore cement traditional divisions of labour (Aisenbrey, Evertsson and Grunow 2009).

In the country chapters (Chapters 4-11) we analyse these three dimensions in light of other existing labour market regulations that concern workers with care obligations, most importantly employment protection, work hours and access to/quality of part-time work. We also see in which ways these dimensions are reflected in the accounts of the parents-to-be. Chapter 2 in this volume provides evidence on the structural aspects and their outcomes in comparative perspective. Going beyond the comparative assessment of family policies our analytical framework relates country-specific policy dimensions to specific dimensions of the dominant gender culture (Pfau-Effinger 2005). Empirically, a gender culture can involve one or more dominant family model(s). We are particularly interested in those models that frame the transition to parenthood and the period following the birth of a child. We expect these models to differ along three interrelated theoretical dimensions, namely widespread societal beliefs about gender equity and men's involvement as carers, mothers' employment and the traditional housewife ideal. The gender culture offers powerful, context-specific guidelines for the gendered division of work and care. These guidelines are sometimes in line with, and other times contradictory to, existing policy frameworks or expectant mothers' and fathers' own gender ideologies. The gender culture is in any case relevant during the construction of gendered parenting identities because it provides guidance in times of perceived uncertainty about the future. It offers a point of reference in terms of 'typical' or 'normal' behaviour and provides knowledge about the possible positive and negative effects of certain choices. In this book we seek 
to uncover the dominant cultural models in the eight countries under study and show how parents-to-be refer to them when speaking about their future division of labour. We also show how degrees of (in)consistency between dominant gender culture(s) and welfare state regulations impact the identity formation of women as mothers and of men as fathers. We refer to these inconsistencies as policy-culture gaps.

\section{Selection and Classification of Countries: Applying the Policy-Culture Gap Scheme}

The countries examined in this volume reflect the broad spectrum of gender culture and family supportive policies in contemporary Europe. We have classified these countries by applying the framework developed earlier in the chapter. While each country's institutional specificities will be discussed in detail in the following chapters, here we introduce their main characteristics, based on comparative macro-level data and analysis, as these guide the order in which the country chapters are presented in this book.

\section{Welfare State Policies and Gender Culture}

Table 1.1 displays the degrees to which the countries contained in this volume promote fathers as carers, mothers' decommodification through defamilialization and mothers' decommodification through supported familialism based on data from the Multilinks Database (Keck and Saraceno 2012). Please note that policies change over time, so that the overview provided in Table 1.1 reflects a snapshot based on data from 2011 (Multilinks 2011). The specific policy settings which apply to the couples in each country during the time of interview are presented in more detail in Chapter 2. While our assessment in Table 1.1 partly builds on the analyses provided by Saraceno and Keck (2011, pp. 393-4), our focus here is exclusively on policies targeting parents of young children. We also apply a slightly less fine-graded classification of policy provisions because we are comparing fewer countries with fewer specificities. In Table 1.1 the promotion of fathers as carers is considered strong when a share of parental leave of at least two months is reserved for fathers and paid at 60 per cent or more of foregone wages. It is considered medium when the leave is paid, but no share is reserved for fathers or when the share that fathers can claim is high, but the leave is compensated at a low rate. In countries with neither a share for fathers nor significant financial compensation during parental leave, the promotion for fathers as carers is classified as weak. Degrees of defamilialization are classified strong when 


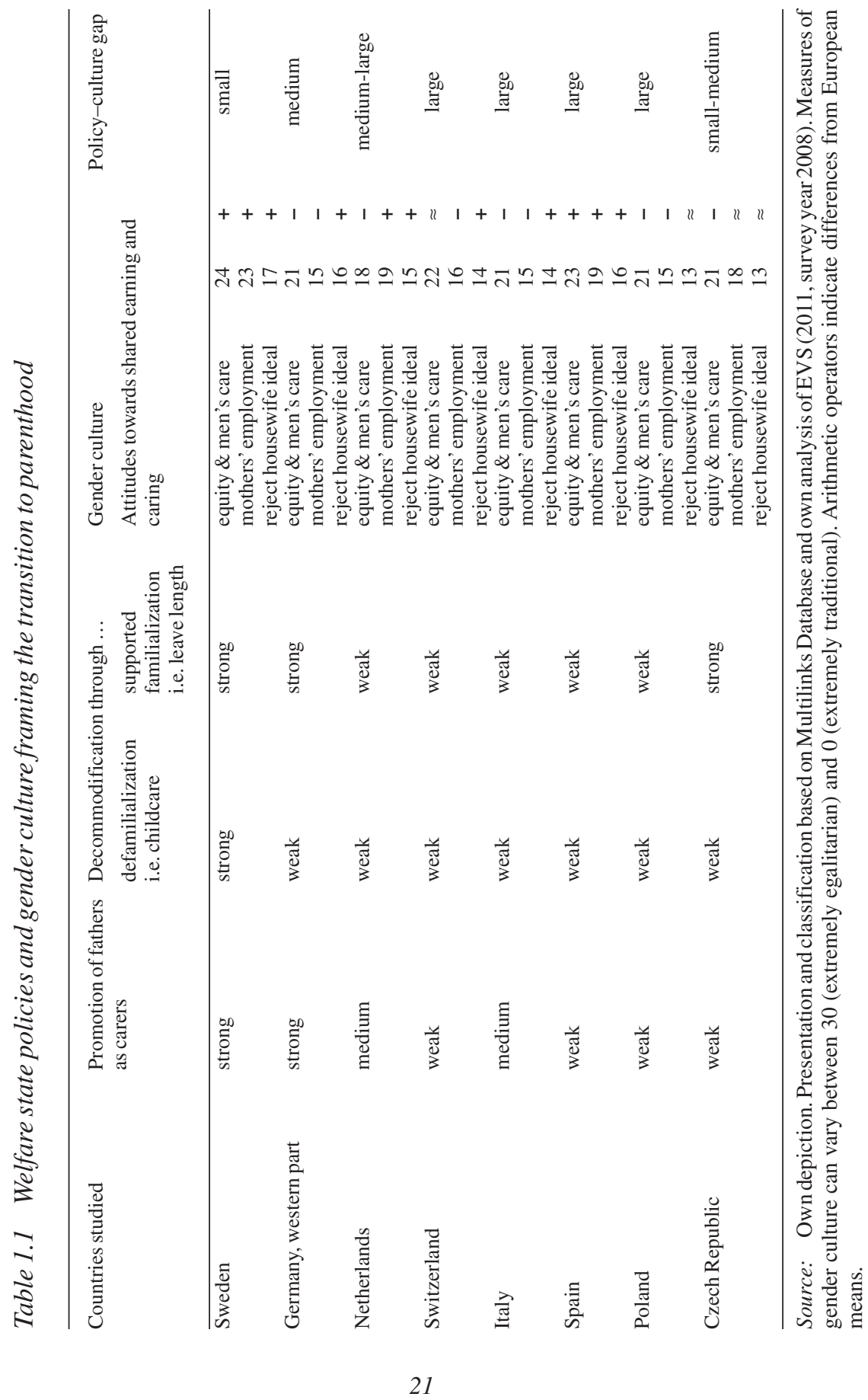


childcare coverage for children under three is higher than 60 per cent, medium when the coverage is between 30 and 60 per cent and weak when coverage is below 30 per cent. To assess the level of supported familialism cross-nationally, a measure of so-called 'effective' parental leave has been employed (Plantenga and Remery 2006). The measure weighs the maximum length of leave available against the duration and level of financial compensation. Applying this measure, supported familialism is considered strong when the maximum effective leave period is 52 weeks or longer, medium when the effective leave is between 26 and 51 weeks, and weak when it is below 26 weeks.

Our assessment of gender culture is based on our analysis of attitudinal data from the European Values Study (EVS). We distinguish three theoretical dimensions: positive attitudes towards gender equity and men's contribution to unpaid work and care (equity \& men's care); positive attitudes towards child well-being and the mother-child relationship when mothers are employed (mothers' employment); and negative attitudes towards female homemaking as a life goal and personal fulfilment (rejection of housewife ideal). ${ }^{5}$ For each theoretical dimension we calculated the country-specific mean value of the respective items (ranging between one and four, rounded to one decimal place), multiplied it by ten and then subtracted this number from 40 . The result is a score which can take any integer value between zero (extremely negative attitude towards shared earning and caring) and 30 (extremely positive attitude towards shared earning and caring). Arithmetic operators indicate whether the respective country value is higher (+), lower (-), or similar $(\approx)$ to the European means of the respective items. ${ }^{6}$ We are aware that the sum scores may hide within country variation in dominant gender ideologies and thus consider them as rough indicators of the overall gender culture.

The last column in Table 1.1 reflects our assessment of countryspecific policy-culture gaps. We consider these gaps small when policies empower new parents to apply a gendered division of work and care that is in line with the cultural dimensions widely shared in their respective society. For instance, strong cultural support for maternal employment and rejection of female homemaking would best be met by strong defamilialization policies. This is the case in Sweden where the policyculture gap is small. If the same cultural ideals are above the European mean in a given country but not represented in national family policies we assess the policy-culture gap to be large. Cultural ideals of gender equity and men's contribution to care would call for policies supporting men's role as carers and strong defamilialization policies. The same strong policies would, in contrast, result in a misfit and hence a large 
policy-culture gap in countries with weak cultural support for men's care work and weak support for maternal employment. Below, we discuss the policy-culture gap for each country and formulate expectations regarding how the fit between family supportive policies and dominant gender ideology may frame couples' situations differently.

Sweden belongs to the Scandinavian countries that emphasize a dual earner-carer strategy (Korpi, Ferrarini and Englund 2013; Misra, Budig and Moller 2007). Together with other Scandinavian countries, most notably Denmark, Sweden is often looked at as a role model for other European countries that politically seek to foster gender equality. This leading role is also mirrored in Swedish gender culture. With respect to all three gender culture dimensions, Swedes embrace on average more egalitarian attitudes compared to the European mean and other countries represented in this volume (Table 1.1). Nevertheless, gendered patterns can still be found in the working and family lives of Swedes (Holth, Jordansson and Gonäs 2012; Chapter 4). Turning to our measure of fit between Swedish family policies and respective dimensions of gender culture, the policy-culture gap appears to be small. In comparative perspective, the Swedish setting clearly supports couples who are committed to gender equality themselves. It is important to note, however, that the Swedish couples studied in this volume may have more difficulty articulating traditional gender ideologies compared to the other couples.

Western Germany and the Netherlands promoted a traditional male breadwinner and female homemaker model throughout most of the twentieth century. From the mid-1980s onwards both have been transforming their family policies in the direction of less gendered separate spheres. Most importantly, both countries started supporting fathers' involvement as carers for their children by offering them access to parental leave. Recent reforms in German family law have been inspired by Swedish policies, most notably the introduction of the so-called 'daddy months' in 2007 and an earnings-related compensation scheme for parents on leave. Both measures made it more attractive for fathers to claim parental leave. The German fathers-to-be studied in this volume had their first child in the year before the 2007 reforms and - with one exception - did not even consider claiming the parental leave they were entitled to at the time (Chapter 5). On average, Germans living in the western part of Germany provide rather weak normative support for gender equity and men's care. Couples determined to stick to an egalitarian gendered division of labour upon entering parenthood will thus face normative obstacles to shared earning and caring. Female homemaking is not idealized any longer, but the idea of mothers working when children are young is not yet widely accepted (see Table 1.1). In 
line with these attitudes, the long parental leave available to working parents offers a culturally acceptable alternative for mothers to exit the labour force or continue working: the mothers (and in principle also the fathers) studied in this edited volume are entitled to up to three years of parental leave which enables them to perform intensive mothering while keeping their jobs. Overall, we consider the policy-culture gap in the western part of Germany as medium.

We expect the Dutch policy-culture gap to be larger, for two reasons. First, despite the efforts made by the Dutch government in recent decades to establish a new family ideal of dual caring (Kremer 2007), cultural support of gender equity and men's care among the Dutch population is still surprisingly low. Second, policy attempts to meet the Dutch populations' positive attitudes towards mothers as workers have been rather limited as childcare is private and thus costly and parental leave is unpaid (see Chapters 2 and 6). For the Dutch mothers-to-be studied in this volume, these conditions leave few alternatives to returning to their jobs part-time right after maternity leave. Those favouring a longer time-out would need to overcome both normative and financial obstacles. Dutch fathers-to-be are in a more ambiguous situation because the norm of dual caring, which is reflected in their right to part-time parental leave, is not clearly mirrored in the general attitudes held by the Dutch population. Hence, Dutch fathers might not consider their legal right to claim parental leave a real option if, for instance, their employers or colleagues do not support them. It is also unclear to what extent our male interviewees embrace the norm of dual caring themselves.

Swiss family policies reflect the traditional ideology of gendered separate spheres most clearly as they neither offer support for fathers as carers nor acknowledge mothers as workers, despite high rates of female labour force participation (Brewster and Rindfuss 2000). Attitudes towards mothers as workers are on average more negative among the Swiss compared to the European mean. However, female homemaking is no longer accepted either. This normative setting puts working mothersto-be in Switzerland in a difficult position and poses both a cultural and practical dilemma, which is expressed in our assessment of a large policy-culture gap.

The state also does little in Italy and Spain to grant caregivers independence from the market, and families therefore depend on paid employment and family solidarity. Often several generations support each other financially and socially by providing care (Naldini and JuradoGuerrero 2009; Nazio 2007; Pisati and Schizzerotto 2006). The couples presented in this volume were interviewed during the 2007-08 economic crisis, implying a high level of financial uncertainty. The lack of state 
support for parents' joint employment and care revitalizes traditional parenting ideals in Italy (see Table 1.1 and Chapter 8). In Spain, in contrast, the traditional gender culture appears to have declined strongly, which is reflected in the comparatively high mean levels of support for gender equity, men's role as carers and maternal employment (see Table 1.1 and Chapter 9). Men's role as earners is weakened in times of economic crisis and several of the fathers-to-be interviewed for this volume fear for their jobs or are currently unemployed (Chapter 9). Their female partners might be forced to continue working regardless of their actual gender ideology or preferences, while lacking the legal right to work part-time or having access to public childcare for their infants (see Chapter 2). We consider the policy-culture gaps to be large in both countries.

Poland and the Czech Republic are countries with a post-socialist legacy of high female employment and full-time jobs. After the fall of the communist regime, the two countries adopted different family policies and care ideals in the 1990s and 2000s (Ferrarini and Sjöberg 2010; Hamplová 2006; Mariková 2005). The polish system expects mothers to quickly return to full-time work, while offering little institutional support for working parents (see Chapter 10). At the same time, normative support for gender equity and maternal employment is comparatively low among the Polish population and significantly lower compared to the European average (Table 1.1). Polish dual-earner couples face a rather large policy-culture gap during their transition to parenthood. What's more, the couples interviewed for this volume deviate markedly from their average polish peers with respect to their cosmopolitan life style and strong commitment to gender equality (Chapter 10). When deciding about their future division of paid work and care, these polish couples truly swim against the current of traditional gender culture and lacking institutional support for working families. The Czech couples studied in this volume, in contrast, appear to embrace a more traditional gender culture, which is widely shared by Czech society (Chapter 11). Czech family policies actively foster maternal caregiving among working women by allowing for long maternity leaves. Hence, the policy-culture gap faced by Czech parents-to-be should be lower than that found in Poland.

\section{STRUCTURE OF THE BOOK}

The structure of this book reflects our aim to compare transitions to first-time motherhood and fatherhood both cross-nationally and also 
in-depth within their specific institutional setting. While each chapter of this edited volume can be read individually, we recommend reading the first three chapters first. This chapter has comprehensively presented the theoretical and analytical framework underlying this book. Chapter 2 presents a macro-comparative analysis of how the countries included in this edited volume differ with respect to social policies, family policies, and resulting employment patterns among men and women. In Chapter 3, we explain our empirical framework and methodological approach. Chapters 4 to 11 are the country-specific studies. Each country chapter provides detailed information on the specific institutional and cultural constellations. These constellations, we argue, frame the more specific conditions of the interviewed couples. The country chapters exemplify how expectant first-time mothers and fathers envision and plan their transition to parenthood and examine how these plans and expectations relate to the interplay between the dominant gender culture and structural opportunities and constraints. While the country chapters refer to one another by pointing out specific cross-national similarities and differences, a comprehensive cross-national comparison of the country-specific findings is presented in the concluding chapter of this book (Chapter 12).

\section{ACKNOWLEDGEMENT}

The research leading to these results has received funding from the European Research Council under the European Union's Seventh Framework Programme (FP/2007-2013) / ERC Grant Agreement no. 263651.

\section{NOTES}

1. In the Netherlands and Spain additional couple interviews were conducted to accompany the individual interviews.

2. As Miller $(2005,2007)$ shows in her longitudinal analysis of transitions to motherhood in Great Britain, expectations of motherhood differ from experiences of motherhood. The former is clearly shaped more by cultural expectations, which are of central relevance in this book.

3. McNay (1999, p. 102) argues that people in a specific context are inclined to behave in a certain way because the active presence of their past is embedded in the structures of their 'habitus'. The habitus is thus a set of embodied dispositions that gives an individual a practical 'feel for the game' in their specific environment. This is in line with Schütz's (1972) theory of social action, in which he elaborates how people use previous experiences to understand the world around them and how they base their actions on these interpretive schemes to give meaning to the world.

4. This premise is perhaps known best as 'bounded rationality' (Simon 1972). The concept of 'bounded rationality' embraces two linked components: the limitations of the human mind to process information and the environmental structure within which the human mind 
operates. With respect to individual decision-making, these restrictions imply that information search processes are limited and decisions are usually satisfying or adaptive, rather than optimizing (Gigerenzer and Todd 1999).

5. The index equity \& men's care consists of agreement with the statements 'fathers are as well suited to look after children as mothers', 'men should take the same responsibility for home and children', 'husband and wife should both contribute to the household income', and 'having a paid job is the best way for women to gain independence'. The index mothers' employment consists of agreement with the statements 'a working mother can have as warm a relationship with her children' and 'a pre-school child suffers when the mother is working' (reversed response categories). The index reject housewife ideal consists of agreement with the statements 'being a housewife is just as fulfilling as having a paid job' (reversed response categories) and 'women really want to have a home and children' (reversed response categories). Calculations are based on weighed country data (considering regional split-ups for eastern and western Germany).

6. European means were calculated based on weighted mean values across all respondents of the 46 EVS countries and correspond to 22 for equity \& men's care, 18 for mothers' employment and 13 for female homemaking.

\section{REFERENCES}

Aisenbrey, S., M. Evertsson and D. Grunow (2009) 'Is there a career penalty for mothers' time out? A comparison of Germany, Sweden and the United States', Social Forces, 88 (2): 573-606.

Baxter, J., S. Buchler, F. Perales and M. Western (2014) 'A life-changing event: first births and men's and women's attitudes to mothering and gender divisions of labor', Social Forces, 93 (3): 989-1014.

Beck, U. and E. Beck-Gernsheim (2002) Individualization: Institutionalized Individualism and its Social and Political Consequences. Theory, Culture \& Society, London, Thousand Oaks, CA: Sage Publications.

Becker, G.S. (1981) A Treatise on the Family, Cambridge: Harvard University Press.

Bergman, H. and B. Hobson (2002) 'Compulsory fatherhood: the coding of fatherhood in the Swedish welfare state', in B.M. Hobson (ed.), Making Men into Fathers. Men, Masculinities, and the Social Politics of Fatherhood, Cambridge, UK, New York: Cambridge University Press, pp. 92-124.

Bielby, W.T. and D.D. Bielby (1989) 'Family ties: balancing commitment to work and family in dual earner households', American Sociological Association, 54 (5): 776-89.

Bittman, M., P. England, N. Folbre and G. Matheson (2003) 'When does gender trump money? Bargaining and time in household work', American Journal of Sociology, 109 (1): 186-214.

Blossfeld, H.P. (2009) 'Educational assortative marriage in comparative perspective', Annual Review of Sociology, 35 (1): 513-30.

Blossfeld, H.P. and A. Timm (eds) (2003) Who Marries Whom?: Educational Systems as Marriage Markets in Modern Societies, Dordrecht: Kluwer Academic Publishers.

Blossfeld, H.P., E. Klijzing, M. Mills and K. Kurz (eds) (2005) Globalization, Uncertainty and Youth in Society: The Losers in a Globalizing World, London: Routledge. 
Bonke, J. and G. Esping-Andersen (2011) 'Family investments in childrenproductivities, preferences, and parental child care', European Sociological Review, 27 (1): 43-55.

Bornstein, M.H. and C.S.L. Cheah (2006) 'The place of "Culture and Parenting" in the ecological contextual perspective on developmental science', in K.H. Rubin and O.B. Chung (eds) Parenting Beliefs, Behaviors, and Parent-Child Relations. A Cross-Cultural Perspective, New York: Psychology Press, pp. 3-34.

Brewster, K.L. and R.R. Rindfuss (2000) 'Fertility and women's employment in industrialized nations', Annual Review of Sociology, 26: 271-96.

Bühlmann, F., G. Elcheroth and M. Tettamanti (2010) 'The division of labour among European couples: the effects of life course and welfare policy on value-practice configurations', European Sociological Review, 26 (1): 49-66.

Charles, M. and D.B. Grusky (2004) Occupational Ghettos: The Worldwide Segregation of Women and Men, California: Stanford University Press.

Chodorow, N.J. (1999) The Reproduction of Mothering: Psychoanalysis and the Sociology of Gender, Oakland, CA: University of California Press.

Cooke, L.P. (2004) 'The gendered division of labor and family outcomes in Germany', Journal of Marriage and Family, 66 (5): 1246-59.

Cornell, R.W. and J.W. Messerschmidt (2005) 'Hegemonic masculinity: rethinking the concept', Gender \& Society, 19 (6): 829-59.

Davis, S.N. and T.N. Greenstein (2009) 'Gender ideology: components, predictors, and consequences', Annual Review of Sociology, 35 (1): 87-105.

Deutsch, F. (1999) Halving It All: How Equally Shared Parenting Works, Cambridge: Harvard University Press.

Deutsch, F. (2007) 'Undoing gender', Gender \& Society, 21 (1): 106-27.

Devereux, E.C., U. Bronfenbrenner and R.R. Rodgers (1969) 'Child-rearing in England and the United States: a cross-national comparison', Journal of Marriage and Family, 31 (2): 257-70.

Dorius, S.F. and D.F. Alwin (2010) The Global Development of Egalitarian Beliefs - A Decomposition of Trends in the Nature and Structure of Gender Ideology, accessed January 2016 at www.psc.isr.umich.edu/pubs/pdf/rr10723.pdf.

Elder, G.H. (1998) 'The life course as developmental theory', Child Development, 69 (1): 1-12.

Eliot, L. (2012) Pink Brain, Blue Brain: How Small Differences Grow Into Troublesome Gaps - And What We Can Do About It, Richmond: Oneworld.

Elster, J. (1983) Sour Grapes: Studies in the Subversion of Rationality, Paris: Cambridge University Press.

Emirbayer, M. and A. Mische (1998) 'What is agency?', American Journal of Sociology, 103 (4): 962-1023.

England, P. (2006) 'Toward gender equality: progress and bottlenecks', in F.D. Blau, M.C. Brinton and D.B. Grusky (eds) The Declining Significance of Gender? New York: Russell Sage Foundation, pp. 245-64.

England, P. (2008) Understanding the Asymmetry of Gender Change. Reply to O. Sullivan \& S. Coltrane (2008). Men's Changing Contribution to Housework and Child Care: A Discussion Paper on Changing Family Roles. Council on Contemporary Families Briefing Papers, University of Illinois. 
Esping-Andersen, G. (1990) The Three Worlds of Welfare Capitalism. Princeton: University Press.

Esping-Andersen, G. (1999) Social Foundations of Postindustrial Economies. New York: Oxford University Press.

Evertsson, M. and M. Nermo (2007) 'Changing resources and the division of housework: a longitudinal study of Swedish couples', European Sociological Review, 23 (4): 455-70.

EVS (2011) European Values Study 2008: Integrated Dataset (EVS 2008). GESIS Data Archive, Cologne. ZA4800 Data file Version 3.0.0, doi: 10.4232/ 1.11004.

Fenstermaker, S., C. West and D.H. Zimmerman (1991) 'Gender inequality: new conceptual terrain', in R.L. Blumberg (ed.) Gender, Family, and Economy. The Triple Overlap. Sage Focus Editions: Vol. 125, Newbury Park, California: Sage, pp. 289-307.

Fenstermaker Berk, S. (1985) The Gender Factory: The Apportionment of Work in American Households, New York: Plenum Press.

Ferrarini, T. and O. Sjöberg (2010) 'Social policy and health: transition countries in a comparative perspective', International Journal of Social Welfare, 19: $60-88$.

Fox, B.J. (2009) When Couples Become Parents: The Creation of Gender in the Transition to Parenthood, Ontario: University of Toronto Press.

Fuwa, M. and P.N. Cohen (2007) 'Housework and social policy', Social Science Research, 36 (2): 512-30.

Gerber, A. (2010) 'The letter versus the spirit: barriers to meaningful implementation of gender equality policy in Poland', Women's Studies International Forum, 33 (1): 30-37.

Gerend, S. (2005) "Magdalena versus the nation": Ireland as a apace of compulsory motherhood in Edna O Brien's Down by the River', in S.B. Hardy and C.A. Wiedmer (eds) Motherhood and Space. Configurations of the Maternal through Politics, Home, and the Body, Houndmills, Basingstoke, Hampshire, England, New York: Palgrave Macmillan, pp. 35-53.

Gershuny, J., M. Bittman and J. Brice (2005) 'Exit, voice, and suffering: do couples adapt to changing employment patterns?', Journal of Marriage and Family, 67 (3): 656-65.

Gigerenzer, G. and P.M. Todd (eds) (1999) Simple Heuristics That Make Us Smart, Oxford: Oxford University Press.

Goffman, E. (1976) 'Gender display', Studies in the Anthropology of Visual Communication, 3 (2): 69-77.

Goffman, E. (1977) 'The arrangement between the sexes', Theory and Society, 4 (3): 301-31.

Grunow, D. (2006) Gendered Division of Paid and Unpaid Work at Entry into Parenthood: A Qualitative Cross-National Comparative Panel Study. ESA Qualitative Methods Research Network Conference. Advances in Qualitative Research Practice, Wales.

Grunow, D. (2014) 'Aufteilung von Erwerbs-, Haus- und Familienarbeit in Partnerschaften im Beziehungsverlauf. Der Einfluss von Sozialpolitik in Europa', in D. Lück and W. Cornelißen (eds) Geschlechterunterschiede und Geschlechterunterscheidungen in Europa, Stuttgart: Lucius, pp. 237-63. 
Grunow, D., F. Schulz and H.P. Blossfeld (2012) 'What determines change in the division of housework over the course of marriage?', International Sociology, 27 (3): 289-307.

Gupta, S. (2007) 'Autonomy, dependence, or display? The relationship between married women's earnings and housework', Journal of Marriage and Family, 69 (2): 399-417.

Gupta, S., M. Evertsson, D. Grunow, M. Nermo and L.C. Sayer (2010) 'Economic inequality and housework', in S. Drobnič and J. Treas (eds) Dividing the Domestic, Stanford: Stanford University Press, pp. 105-22.

Hamplová, D. (2006) 'Women and the labor market in the Czech Republic: transition from a socialist to a social-democratic regime?', in H.P. Blossfeld and H.A. Hofmeister (eds) Globalization, Uncertainty and Women's Careers. An International Comparison, Cheltenham, UK, Northampton, MA: Edward Elgar, pp. 224-46.

Hays, S. (1996) The Cultural Contradictions of Motherhood, Newhaven, CT: Yale University Press.

Hitlin, S. and G.H. Elder (2007) 'Time, self, and the curiously abstract concept of agency', Sociological Theory, 25 (2): 170-91.

Hobson, B. and S. Fahlén (2009) 'Competing scenarios for European fathers: applying Sen's capabilities and agency framework to work-family balance', The ANNALS of the American Academy of Political and Social Science, 624 (1): 214-33.

Hochschild, A. and A. Machung (2012) 'The second shift: working families and the revolution at home', first published 1989, New York: Penguin.

Hoffman, D.M. (2010) 'Risky investments: parenting and the production of the "resilient child", Health, Risk and Society, 12 (4): 385-94.

Holth, L., B. Jordansson and L. Gonäs (2012) 'Gender and the division of labour in a Swedish context', in M.J. Samuelsson, C. Krekula and M. Åberg (eds) Gender and Change. Power, Politics and Everyday Practices, Sweden: Karlstad University Press, pp. 74-94.

Kaufmann, J.C. (1998) Dirty Linen: Couples and their Laundry. Material Culture Series, Middlesex University Press.

Keck, W. and C. Saraceno (2012) 'Multilinks database on intergenerational policy indicators', Schmollers Jahrbuch: Journal of Applied Social Science Studies/Zeitschrift für Wirtschafts-und Sozialwissenschaften, 132 (3): 453-61.

Knaak, S.J. (2010) 'Contextualising risk, constructing choice: breastfeeding and good mothering in risk society', Health, Risk \& Society, 12 (4): 345-55.

Korpi, W., T. Ferrarini and S. Englund (2013) 'Women's opportunities under different family policy constellations: gender, class, and inequality tradeoffs in western countries re-examined', Social Politics: International Studies in Gender, State \& Society, 20 (1): 1-40.

Kremer, M. (2007) How Welfare States Care: Culture, Gender and Parenting in Europe, Amsterdam, The Netherlands: Amsterdam University Press.

Kühhirt, M. (2012) 'Childbirth and the long-term division of labour within couples: how do substitution, bargaining power, and norms affect parents' time allocation in West Germany?', European Sociological Review, 28 (5): 565-82. 
Lewis, J. (2006) 'Employment and care: the policy problem, gender equality and the issue of choice', Journal of Comparative Policy Analysis: Research and Practice, 8 (2): 103-14.

Lorber, J. (1994) Paradoxes of Gender, New Haven, CT: Yale University Press.

Lorber, J. (2000) 'Using gender to undo gender: a feminist degendering movement', Feminist Theory, 1 (1): 79-95.

Lück, D. (2006) 'The impact of gender role attitudes on women's life courses', in H.P. Blossfeld and H.A. Hofmeister (eds) Globalization, Uncertainty and Women's Careers. An International Comparison, Cheltenham, UK, Northampton, MA: Edward Elgar, pp. 405-32.

Mahmood, S. (2001) 'Feminist theory, embodiment, and the docile agent: some reflections on the Egyptian Islamic revival', Cultural Anthropology, 16 (2): 202-36.

Mandel, H. and M. Semyonov (2006) 'A welfare state paradox: state interventions and women's employment opportunities in 22 countries', American Journal of Sociology, 111 (6): 1910-49.

Mariková, H. (2005) 'The Czech family at present and in the recent past', in M. Robila (ed.) Families in Eastern Europe. Contemporary Perspectives in Family Research, Bingley: Emerald Group Publishing Limited, pp. 29-47.

McNay, L. (1999) 'Gender, habitus and the field: Pierre Bourdieu and the limits of reflexivity', Theory, Culture \& Society, 16 (1): 95-117.

Miller, T. (2005) Making Sense of Motherhood: A Narrative Approach, Cambridge: Cambridge University Press.

Miller, T. (2007) "'Is this what motherhood is all about?": weaving experiences and discourse through transition to first-time motherhood', Gender \& Society, 21 (3): 337-58.

Miller, T. (2010) Making Sense of Fatherhood: Gender, Caring and Work, Cambridge: Cambridge University Press.

Mills, M., L. Mencarini, M.L. Tanturri and K. Begall (2008) 'Gender equity and fertility intentions in Italy and the Netherlands', Demographic Research. Special Collection 04/2004, 18: 1-26.

Misra, J., M.J. Budig and S. Moller (2007) 'Reconciliation policies and the effects of motherhood on employment, earnings and poverty', Journal of Comparative Policy Analysis: Research and Practice, 9 (2): 135-55.

Multilinks (2011) Multilinks Database on Intergenerational Policy. Version 2.0. Multilinks Project and Wissenschaftszentrum Berlin für Sozialforschung (WZB), accessed March 2015 at http://multilinks-database.wzb.eu/.

Naldini, M. and T. Jurado-Guerrero (2009) 'The changing South European family', in H.G. Puhle, R. Gunther and N. Diamondouros (eds) Democracy and Cultural Change in the New Southern Europe, NSE Volume 5, forthcoming with Oxford University Press.

Nazio, T. (2007) Cohabitation, Family, and Society. Routledge Advances in Sociology, New York: Routledge.

Neale, B. and C. Smart (2002) 'Parenthood and employment after divorce', in A.H. Carling, S. Duncan and R. Edwards (eds) Analysing Families: Morality and Rationality in Policy and Practice, New York: Routledge, pp. 183-98. 
Orloff, A.S. (2003) 'Markets not states? The weakness of state social provision for breadwinning men in the U.S.', in L. Haney and L. Pollard (eds) Families of a New World, New York: Routledge, pp. 217-45.

Pfau-Effinger, B. (2005) 'Culture and welfare state policies: reflections on a complex interrelation', Journal of Social Policy, 34 (1): 3-20.

Pfau-Effinger, B. (2012) 'Women's employment in the institutional and cultural context', International Journal of Sociology and Social Policy, 32 (9): 530-43.

Pfau-Effinger, B. and T. Euler (2014) 'Wandel der Einstellungen zu Kinderbetreuung und Elternschaft in Europa - Persistenz kultureller Differenzen', Soziale Welt, 20: 175-93.

Pinchbeck, I. (2013) Women Workers in the Industrial Revolution, New York: Routledge.

Pisati, M. and A. Schizzerotto (2006) 'Mid-career women in contemporary Italy: economic and institutional changes', in H.P. Blossfeld and H.A. Hofmeister (eds) Globalization, Uncertainty and Women's Careers. An International Comparison, Cheltenham, UK, Northampton, MA: Edward Elgar, pp. 352-75.

Plantenga, J. and C. Remery (2006) The Gender Pay Gap. Origins and Policy Responses, Luxembourg: Office for Official Publications of the European Communities.

Ramaekers, S. and J. Suissa (2010) 'The scientisation of the parent-child relationship', in L. Hopkins, M. Macleod and W.C. Turgeon (eds) Negotiating Childhoods, Oxford: Inter-Disciplinary Press, pp. 179-87.

Ridgeway, C.L. (2011) Framed by Gender: How Gender Inequality Persists in the Modern World, New York: Oxford University Press.

Risman, B.J. (2004) 'Gender as a social structure: theory wrestling with activism', Gender \& Society, 18 (4): 429-50.

Ritzer, G. (2007) The Blackwell Encyclopedia of Sociology (Vol. 1479), Malden, MA: Blackwell Publishing.

Romagnoli, A. and G. Wall (2012) “I know I'm a good mom”: young, low-income mothers' experiences with risk perception, intensive parenting ideology and parenting education programmes', Health, Risk \& Society, 14 (3): 273-89.

Rubin, K.H. and O.B. Chung (eds) (2006) Parenting Beliefs, Behaviors, and Parent-Child Relations: A Cross-Cultural Perspective, New York: Psychology Press.

Ruhm, C.J. (1998) 'The economic consequences of parental leave mandates: lessons from Europe', The Quarterly Journal of Economics, 113 (1): 285-317.

Saraceno, C. and W. Keck (2011) 'Towards an integrated approach for the analysis of gender equity in policies supporting paid work and care responsibilities', Demographic Research, 25: 371-406.

Schober, P.S. (2013) 'The parenthood effect on gender inequality: explaining the change in paid and domestic work when British couples become parents', European Sociological Review, 29 (1): 74-85.

Schütz, A. (1972 [1932]) The Phenomenology of the Social World, London: Heinemann.

Sen, A. (2003) 'Capability and well-being', in M.C. Nussbaum and A. Sen (eds), The Quality of Life, Oxford, UK: Oxford University Press, pp. 30-53. 
Simon, H.A. (1972) 'Theories of bounded rationality', in J. Marschak, C.B. McGuire, R. Radner and K.J. Arrow (eds) Studies in Mathematical and Managerial Economics: Vol. 12. Decision and Organization. A Volume in Honor of Jacob Marschak, Amsterdam: North-Holland, pp. 161-76.

Stähli, M.E., J.M. Le Goff, R. Levy and E. Widmer (2009) 'Wishes or constraints? Mothers' labour force participation and its motivation in Switzerland', European Sociological Review, 25 (3): 333-48.

Tilly, L.A. (1994) 'Women, women's history, and the industrial revolution', Social Research, 61 (1): 115-37.

Tilly, L.A. and J.W. Scott (1987) Women, Work, and Family, Hove, UK: Psychology Press.

Van Berkel, M. and N.D. De Graaf (1999) 'By virtue of pleasantness? Housework and the effects of education revisited', Sociology, 33 (4): 785-808.

Wall, G. (2010) 'Mothers' experiences with intensive parenting and brain development discourse', Women's Studies International Forum, 33 (3), 253-63.

Walzer, S. (1998) Thinking About the Baby: Gender and Transitions into Parenthood. Women in the Political Economy, Philadelphia, PA: Temple University Press.

West, C. and D.H. Zimmerman (1987) 'Doing gender', Gender and Society, 1 (2): 125-51.

Zelizer, V.A. (1989) 'The social meaning of money: "special monies", American Journal of Sociology, 95 (2): 342-77. 